\title{
Bazaltik Kayaların Bileşim ve Dokusal Özelliklerinin Mekanik Davranışlarına Etkisi
}

\author{
The Effect of Composition and Textural Properties of Basaltic Rocks on Their Mechaical \\ Behaviour
}

\author{
Sinem ERIşiș $\mathbb{D}$, Atiye TUĞRUL $\mathbb{D}$, Selman ER $\mathbb{D}$, Murat YILMAZ* (D) \\ İstanbul Üniversitesi-Cerrahpaşa, Mühendislik Fakültesi, Jeoloji Mühendisliği Bölümü, 34320, Avcılar-İstanbul
}

Geliş (Received): 01 Şubat (February) 2019 / Düzeltme (Revised): 16 Nisan (April) 2019 / Kabul (Accepted): 19 Nisan (April) 2019

Bazaltlar ülkemizde yaygın bir şekilde bulunmakta ve çeşitli amaçlar için kullanılmaktadır. Dayanıklılığı ve dayanımı yüksek olan bazaltlar mühendislik projelerinde tercih edilmektedir. Kullanım alanlarının artması için bazaltların kimyasal, mineralojik, petrografik ve fiziko-mekanik özelliklerinin çok iyi bilinmesi gerekmektedir. $\mathrm{Bu}$ çalışmada farklı kimyasal, mineralojik ve petrografik özelliklere sahip bazaltik kayaların fiziko-mekanik davranışlarına olan etkilerinin araştııılması amaçlanmıştır. Örnekler genel olarak Marmara Bölgesi ve çevresindeki bazalt taş ocaklarından derlenmiştir. Daha sonra örneklerin kimyasal, mineralojik ve petrografik özellikleri belirlenmiştir. Sonraki aşamada laboratuvar çalışmaları sonucunda fiziko-mekanik özellikleri tespit edilmiştir. Elde edilen sonuçlara göre bazaltlar hamur özellikleri, mineralojik bileşimleri ve fenokristal boyutlarına göre iki gruba ayrılmıştır. Birinci grup bazaltlar olivin içeriği yüksek ve fenokristal minerallerin alanları düşük bazaltlardır. İkinci grup bazaltlar ise olivin içermeyen, volkan camı içeriği ve fenokristal minerallerin alanları yüksek olan bazaltlardır. Birinci grup bazaltlar ikinci grup bazaltlara göre daha yüksek dayanım vermektedir.

Anahtar Kelimeler: Bazalt, Mineraloji, Dokusal Özellik, Fiziko-Mekanik

\begin{abstract}
Basalts are common in our country and basalts are employed for different purposes. Basalts which have high durability and resistance are preferred in engineering projects. Chemical, mineralogical, petrographic and physicomechanical properties of basalts should be well-known to increase their usage areas. Studies have shown that there is a relationship between the structure and physico-mechanical properties of stones. The aim of this study is to investigate the effects of different chemical, mineralogical and petrographic properties on the physico-mechanical behavior of basaltic rocks. In general, basalt stones were collected from the Marmara Region and its surroundings. Then, chemical, mineralogical and petrographic properties of the samples were determined. In the next stage, physico-mechanical properties were determined as a result of laboratory studies. Basalts were divided into two groups according to their matrix characteristics, mineralogical composition and phenocrystalline dimensions according to test results. The first group of basalts showed high strength with high olivine content. The second group of basalts are including high rate phenocrystalline minerals, not including olivine but including high volcanic glass. These basalts give lower strength than the first group.
\end{abstract}

Key words: Basalt, Mineralogy, Textural Properties, Pyhsico-Mechanic 


\section{GİRIŞ}

Ülkemizde köprü, yol, metro, demiryolu, tünel ve baraj gibi mühendislik yapılarının sayısı arttıkça doğal kaynak ihtiyacı da artmaktadır. Sadece mühendislik yapıları değil, toplu yaşam alanlarına her geçen gün bir yenisinin eklenmesi ve bunların dışında farklı sektörlerdeki (1s1 depolama, 1s1 yalıtımı, cam-seramik gibi) doğal taş kullanımı, kaynak ihtiyacını arttırmaktadır. $\mathrm{Bu}$ doğrultuda ülkemizde ve dünyada yaygın şekilde bulunan bazaltik kayaçlar, dayanımı ve dayanıklılıklarının yüksek olmasından dolayı çok geniş bir yelpazede malzeme ihtiyacını karşılamaktadır. Farklı türdeki bazaltların yük altındaki davranışlarının veyenilmeözelliklerinin bilinmesi, fiziksel ve mekanik özelliklerinin tespit edilmesine yönelik literatürde birçok çalışma vardır. Tuğrul ve Gürpınar (1997) Tokat/Niksar bölgesinden seçilmiş olan bazaltların temel mühendislik özelliklerini her bir ayrışma zonu için belirlemişlerdir. Mühendislik özellikleri (kuru yoğunluk, gözeneklilik, geçirgenlik, tek eksenli basınç dayanımı, çekme dayanımı ve elastisite modülü değerleri) ile ayrışma zonları arasında ilişkiler olduğunu tespit etmişlerdir. Yaptıkları çalışmalar sonucunda da ayrışmadan etkilenen bazaltik kayaçlar için yeni bir sınıflama sistemi önermişlerdir. Heap (2009) ise elastisite modülünün, deformasyonun kaynağını bulmaya yönelik güvenilir bir yardımc1 olduğunu belirtmiştir. Korkanç ve Solak (2016) yaptığ1 çalışmada tüf ve ignimbiritlerin petrografik özelliklerini incelemiş ve tane/ matriks oranı ile mekanik davranışları arasında ilişkiler kurmuştur. Sonuç olarak tüflerde dayanımı etkileyen en önemli faktörün matriks oranı olduğu ve ignimbiritler için tane /matriks oranı arttıkça dayanımın azaldığı sonucuna varmıştır. Adelinet ve diğerleri (2013) bazaltik kayada kırılgan ve sünek davranışlar sırasında deformasyon gelişimini, sismik aletler, akustik emisyon verileri ve mikro yapıları gözleyerek araştırmışlardır. Hacmin ve yoğunluğun düştüğü yerde çatlakların ilerlediğini ve kayanın orijinal halinde deformasyon farklı1ığını, mikro yapısının ve porozitesinin kontrol ettiğini tespit etmişlerdir.

Ündül vd. (2015) de düşük poroziteli andezitik kayaçlarda, mikro yapının kayanın mühendislik özellikleri üzerindeki etkilerini araştırmışlardır. Sayısal petrografik çalışmalarla birlikte makro ve mikro çatlakların dağılımlarını basınç testleriyle analiz etmişlerdir.

$\mathrm{Bu}$ çalışmalardan da görülebileceği gibi kayaların yük altındaki davranışlarını belirleyecek olan fiziksel ve mekanik özellikler, bileşimleri ve dokularıyla doğrudan ilişkilidir. Farklı tür kayaçlar (granit, bazalt, gabro, andezit gibi) üzerinde yapılan çalışmalar literatürde yer alsa da, farklı tür bazaltlar kullanılarak, tüm fiziksel ve mekanik özelliklerinin bileşim ve doku ile olan ilişkilerini kıyaslayan ve doğrudan ele alan bir çalışmaya rastlanmamıştır. $\mathrm{Bu}$ çalışmanın temel amacı, gerçekleştirilmekte olan alt ve üst yap1 projelerinde kullanımı ve gelişmekte olan farklı sektörler ile birlikte ihtiyacı her geçen gün giderek artan bazaltik kayaçların bileşim ve doku özelliklerinin fiziksel ve mekanik özelliklerine etkisinin ortaya konulmasidır.

\section{MALZEME VE YÖNTEM}

$\mathrm{Bu}$ çalışma için, Marmara Bölgesi ve çevresinde yer alan, farklı doku ve bileşime sahip bazalt örnekleri üzerinde araştırmalar yapılmıştır. Çalışmalarda kullanılan bazalt örnekleri Tekirdağ - Hayrabolu, TekirdağMuratl1, Tekirdağ-Osmanc1k Köyü, Kütahya, Düzce, Çanakkale-Biga, Bursa-İznik ve EdirneKeşan bölgelerindeki taş ocaklarından alınmıştır (Şekil 1). Deneysel çalışmalarda kullanılan örneklere verilen kodlar ve nereden alındıkları Çizelge 1'de sunulmuştur. 


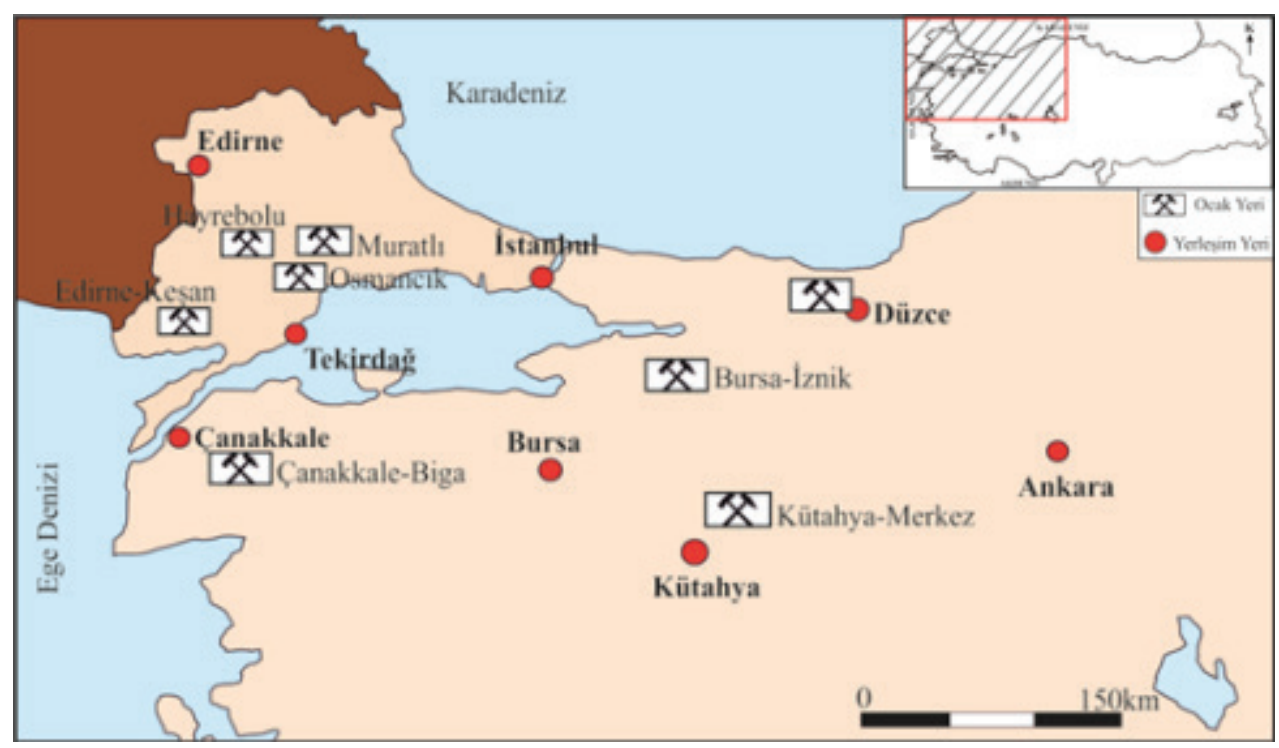

Şekil 1. İncelenen kayaçların alındığı ocak yerlerini gösteren yer bulduru haritası.

Figure 1. Location map showing the places where the investigated rocks were taken.

Çizelge 1. Deneysel çalışmalarda kullanılan bazalt örneklerinin kodları ve alındığı bölgeler.

Table 1. Codes and locations of the basalt samples used in experimental studies.

\begin{tabular}{cc}
\hline Örnek Kodu & Örneğin Alındığı Bölge \\
\hline BTH & Tekirdağ- Hayrabolu \\
BTM & Tekirdağ- Muratlı \\
BTO & Tekirdağ- Osmancık Köyü \\
BK & Kütahya \\
BD & Düzce \\
BÇ & Çanakkale \\
BB & Bursa \\
BE & Edirne \\
\hline
\end{tabular}

Bazaltik kayaların mineralojik ve petrografik özelliklerinin, mekanik davranışlarına etkisinin belirlenebilmesi için öncelikle numunelerden ince kesitler hazırlanmış ve incelenmiştir. Farklı özelliklerdeki bazaltik kayaçların kimyasal bileşimlerini belirlemek için ise XRF analizi yapılmış ve ana element oksit yüzdeleri bulunmuştur. Böylece kimyasal bileşimlerine göre incelenen kayaçlar sınıflandırılmış, mineralojik ve petrografik özellikleri tespit edilmiştir. Bu çalışmaların ardından blok haline getirilmiş olan bazaltik kayaçlardan örnekler hazırlanmıştır. Elde edilen örnekler üzerinde fiziksel ve mekanik deneyler yapılırken ISRM (2007) tercih edilmiştir. (Şekil 2). 


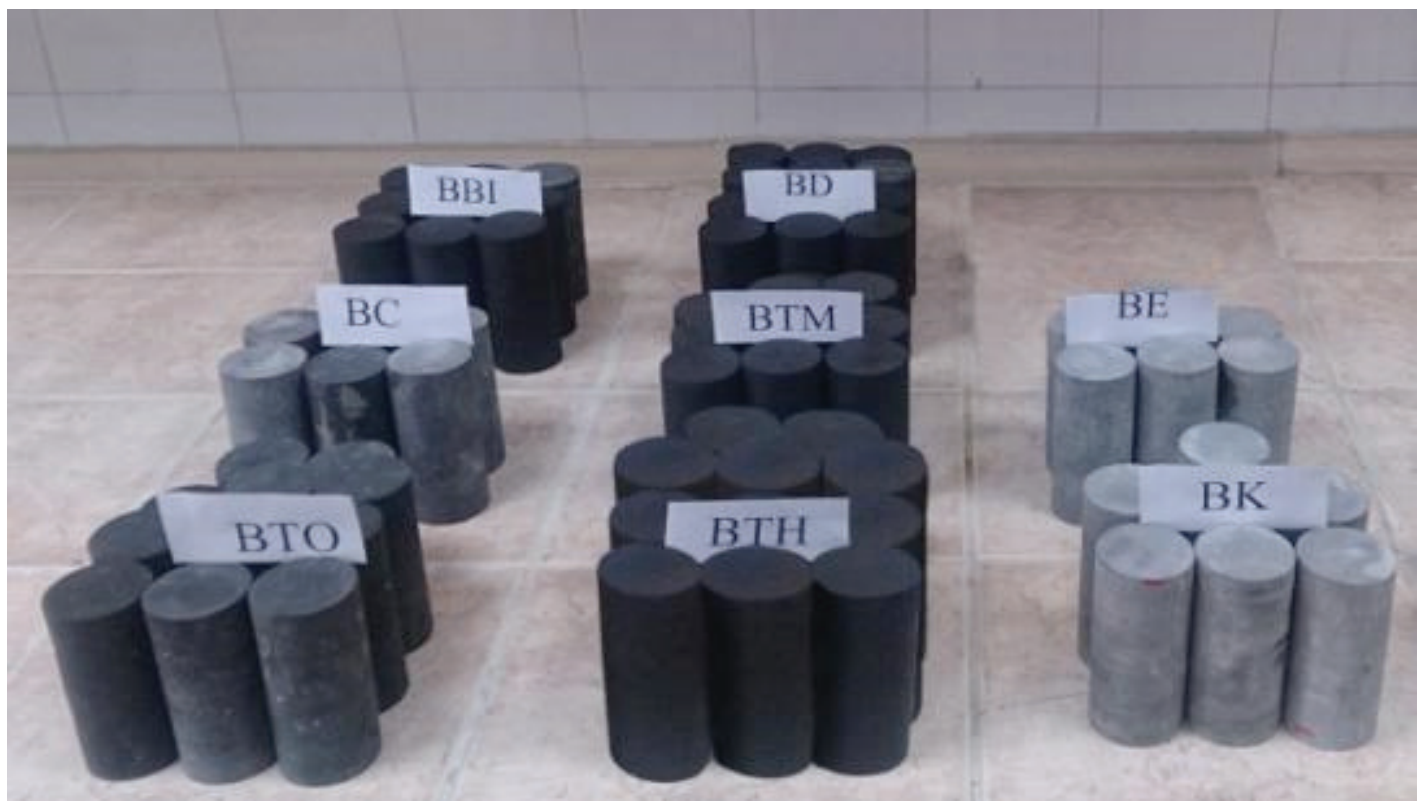

Şekil 2. Laboratuvar çalışmalarında kullanılan bazalt karot örnekleri.

Figure 2. Basalt core samples used in laboratory studies.

\section{BULGULAR}

\section{Kimyasal Özellikler}

Farklı bileşimlere sahip sekiz kayacın kimyasal özelliklerini saptamak amaciyla XRF yöntemi kullanılarak ana element oksit içerikleri belirlenmiştir. Elde edilen sonuçlar Çizelge 2'de sunulmuştur.
Bazaltik kayaçların kimyasal içerikleri doğrultusunda Le Bas vd. (1986)'a göre $\mathrm{Na}_{2} \mathrm{O}+\mathrm{K}_{2} \mathrm{O} / \mathrm{SiO}_{2}$ değerleri kullanılarak örneklerin dağılımları yapılmıștır (Şekil 3). Bu doğrultuda BTH tefrit, BTM bazalt, BTO trakibazalt, BK traki-bazalt, BD andezit, BÇ bazaltik trakiandezit, $\mathrm{BB}$ traki-andezit, BE fenotefritbazaltik trakiandezit bileşimlerindedir (Şekil 3).

Çizelge 2. Bazaltik kayaçların ana element oksit yüzdeleri.

Table 2. Main element oxide percentages of the basaltic rocks.

\begin{tabular}{ccccccccc}
\hline \multirow{2}{*}{ Ocak Kodu } & \multicolumn{7}{c}{ Ana Element Oksit Yüzdeleri (\%) } \\
\cline { 2 - 8 } & $\mathrm{SiO}_{2}$ & $\mathrm{Al}_{2} \mathrm{O}_{3}$ & $\mathrm{Fe}_{2} \mathrm{O}_{3}$ & $\mathrm{CaO}$ & $\mathrm{MgO}$ & $\mathrm{SO}_{3}$ & $\mathrm{~K}_{2} \mathrm{O}$ & $\mathrm{Na}_{2} \mathrm{O}$ \\
\hline $\mathrm{BTH}$ & 46.33 & 13.67 & 10.96 & 9.79 & 11.63 & 0.15 & 2.31 & 4.52 \\
$\mathrm{BTM}$ & 45.14 & 13.25 & 10.19 & 9.08 & 12.11 & 0.16 & 1.90 & 3.04 \\
$\mathrm{BTO}$ & 47.10 & 13.12 & 10.02 & 8.91 & 11.83 & 0.14 & 2.10 & 3.78 \\
$\mathrm{BK}$ & 51.73 & 18.32 & 5.87 & 9.08 & 3.09 & 0.15 & 2.39 & 3.31 \\
$\mathrm{BD}$ & 57.65 & 17.22 & 6.52 & 6.69 & 2.96 & 0.15 & 1.18 & 3.68 \\
$\mathrm{BÇ}$ & 56.63 & 18.52 & 5.95 & 6.65 & 3.34 & 0.15 & 3.28 & 3.03 \\
$\mathrm{BB}$ & 57.13 & 17.75 & 6.96 & 6.75 & 3.81 & 0.15 & 1.96 & 3.43 \\
$\mathrm{BE}$ & 49.67 & 12.26 & 7.89 & 7.91 & 12.74 & 0.14 & 5.51 & 2.53 \\
\hline
\end{tabular}




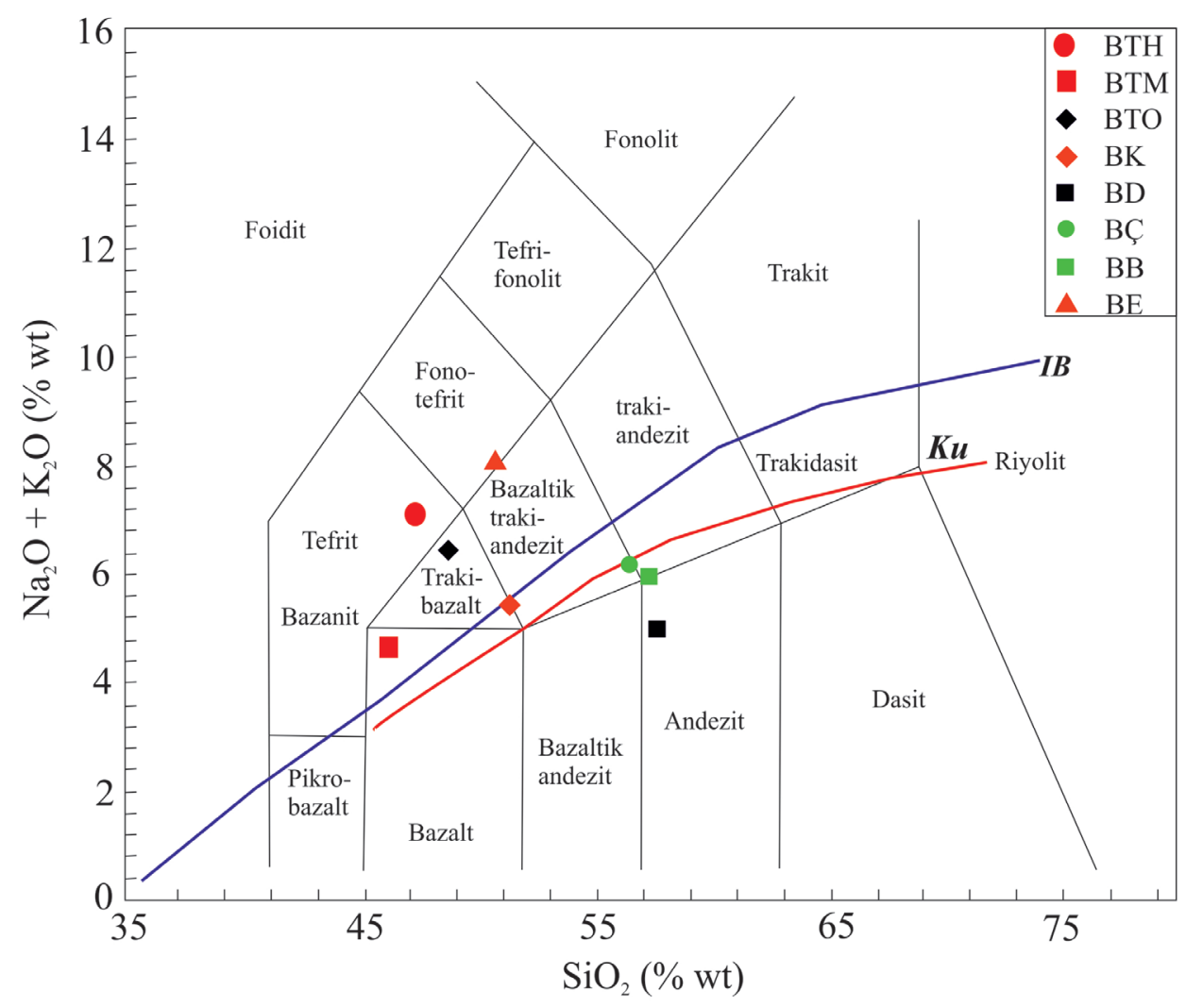

Le Bas ve diğ. 1986

Şekil 3. İncelenen kayaç örneklerinin $\mathrm{Na}_{2} \mathrm{O}+\mathrm{K}_{2} \mathrm{O} / \mathrm{SiO}_{2}$ değerlerine göre isimlendirme diyagramındaki konumları (Le Bas vd., 1986).

Figure 3. The locations of the rock samples in the naming diagram according to $\mathrm{Na}_{2} \mathrm{O}+\mathrm{K}_{2} \mathrm{O} / \mathrm{SiO}_{2}$ (Le Bas et al., 1986).

\section{Mineralojik ve Petrografik Özellikler}

Sekiz farklı bazaltik kayaç örneğinden öncelikle ince kesitler hazırlanmış ve mikroskop altında mineral alanları ve hamur yüzdeleri tespit edilmiştir. İnce kesit incelemeleri sırasında geneli ifade edecek şekilde her bir ocağın kesitinden onar tane olmak üzere toplamda 80 ince kesit fotoğrafı polarizan mikroskopta 100 mikron (um) ölçek kullanılarak çekilmiştir. Çekilen fotoğraflar üzerinde Image J programı kullanılarak tüm ince kesitler için minerallerin alanları ve hamur yüzdeleri hesaplanmıştır. 100um 0.1 mm.' ye karşılık geldiğinden, on ince kesit fotoğrafının toplam alanı da yaklaşı $7,4 \mathrm{~mm}^{2}$ 'ye denk gelmektedir. $\mathrm{Bu}$ nedenle etki oranının yüksek olmamasından dolayı ve hesap karmaşasına yer vermemek adına $0.001 \mathrm{~mm}^{2}$ altındaki alana sahip mineral tanelerinin, toplam mineral değerlerine dahil edilmemesi uygun görülmüştür. İnce kesitler üzerinde bazaltik kayaçların mineralojik bileşimini kantitatif olarak belirlemek amacıyla modal analiz (nokta sayımı) yapılmıştır. Modal analiz için her bir bazalt kesiti üzerinde 2000 
Erişiş, Tuğrul, Er, Yılmaz

nokta sayılmıştır. Bu çalışmalar sonucunda kayaçların mineral - hamur alanları Çizelge 3'te, nokta sayımı ile elde edilen mineral içeriklerinin yüzdeleri de Çizelge 4'te verilmiştir. Bazaltik kayaçların hamur ve doku özellikleri, mineral içerikleri, ayrışma durumları ve petrografik bileşimlerine göre sınıflandırmaları da Çizelge 5'te ve Şekil 4'te verilmiştir.

Çizelge 3. İncelenen bazaltik kayaçların içeriğinde bulunan minerallerin alanları ve yüzdeleri.

Table 3. The areas and percentages of the minerals in the basaltic rocks studied.

\begin{tabular}{lcccccccccccccc}
\hline & \multicolumn{3}{c}{ Hamur } & \multicolumn{2}{c}{ Piroksen } & \multicolumn{2}{c}{ Olivin } & \multicolumn{2}{c}{ Plajiyoklas } & Biyotit & Opak min. \\
Ocak & $\begin{array}{c}\text { Alan } \\
\text { Kodu }\end{array}$ & $\left(\mathrm{mm}^{2}\right)$ & $\left(\mathrm{mm}^{2}\right)$ & $(\%)$ & $\left(\mathrm{mm}^{2}\right)$ & $(\%)$ & $\left(\mathrm{mm}^{2}\right)$ & $(\%)$ & $\left(\mathrm{mm}^{2}\right)$ & $(\%)$ & $\left(\mathrm{mm}^{2}\right)$ & $(\%)$ & $\left(\mathrm{mm}^{2}\right)$ & $(\%)$ \\
\hline BTH & 7.46 & 6.12 & 82.1 & 0.71 & 9.5 & 0.46 & 6.17 & 0.15 & 1.97 & - & - & 0.02 & 0.23 \\
BTM & 7.43 & 5.19 & 69.9 & 0.32 & 4.3 & 0.97 & 13.0 & 0.93 & 12.5 & - & - & 0.02 & 0.23 \\
BTO & 7.43 & 4.78 & 64.0 & 0.63 & 8.4 & 1.23 & 16.5 & 0.68 & 9.18 & - & - & 0.11 & 1.48 \\
BK & 7.44 & 5.77 & 77.6 & 1.35 & 18.2 & 0.15 & 2.06 & 0.12 & 1.60 & - & - & 0.04 & 0.55 \\
BD & 8.19 & 4.97 & 60.6 & 1.22 & 14.8 & - & - & 1.88 & 23.0 & - & - & 0.12 & 1.46 \\
BÇ & 6.68 & 3.86 & 57.7 & 0.95 & 14.2 & - & - & 1.73 & 25.8 & - & - & 0.15 & 2.24 \\
BB & 7.52 & 3.84 & 50.9 & 1.38 & 18.3 & - & - & 2.11 & 28.1 & - & - & 0.19 & 2.57 \\
BE & 7.36 & 3.29 & 44.6 & 2.55 & 34.5 & 0.12 & 1.60 & 1.10 & 14.9 & 0.27 & 3.67 & 0.04 & 0.58 \\
\hline
\end{tabular}

Çizelge 4. Nokta sayımı ile belirlenen bazaltik kayaçların içerdiği mineral oranları.

Table 4. Mineral ratios of the basaltic rocks determined by point counting.

Mineral İçeriği (\%)

\begin{tabular}{lcccccc} 
Ocak Kodu & Hamur & Piroksen & Olivin & Plajiyoklas & Biyotit & Opak Min. \\
\hline BTH & 81.4 & 9.9 & 3.3 & 4.4 & - & 1.0 \\
BTM & 68.2 & 5.6 & 10.5 & 14.2 & - & 1.5 \\
BTO & 65.3 & 7.2 & 15.0 & 10.8 & - & 1.7 \\
BK & 75.7 & 18.5 & 2.80 & 2.60 & - & 0.4 \\
BD & 59.7 & 12.6 & - & 26.9 & - & 0.8 \\
BÇ & 56.6 & 13.0 & - & 29.4 & - & 1.0 \\
BB & 50.5 & 18.5 & - & 30.2 & - & 0.8 \\
BE & 48.5 & 32.2 & 3.8 & 10.8 & 4.1 & 0.6
\end{tabular}




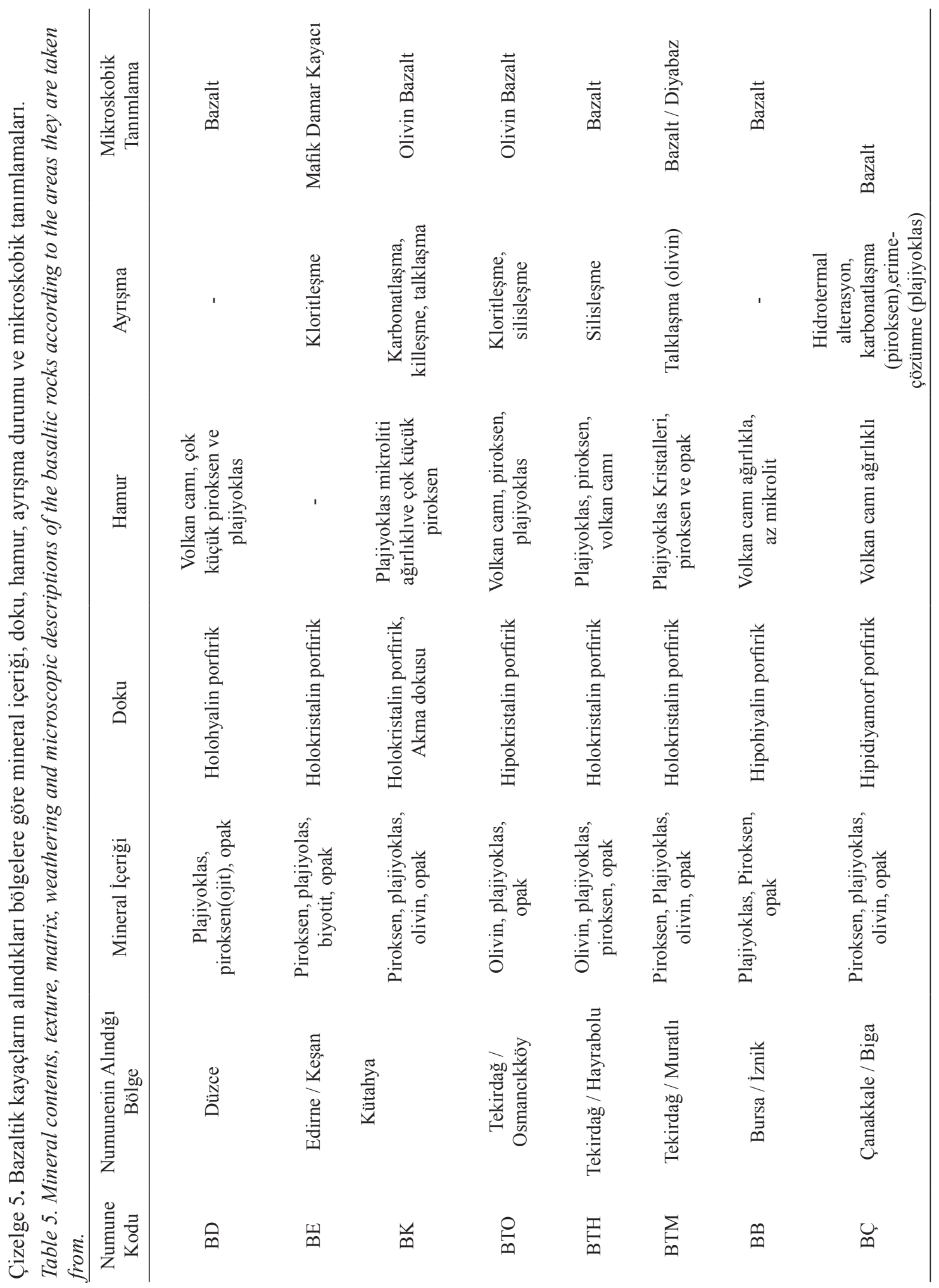


Erişiş, Tuğrul, Er, Yılmaz

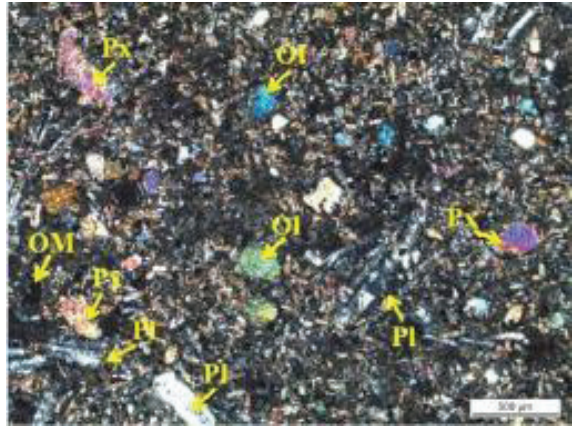

(a)

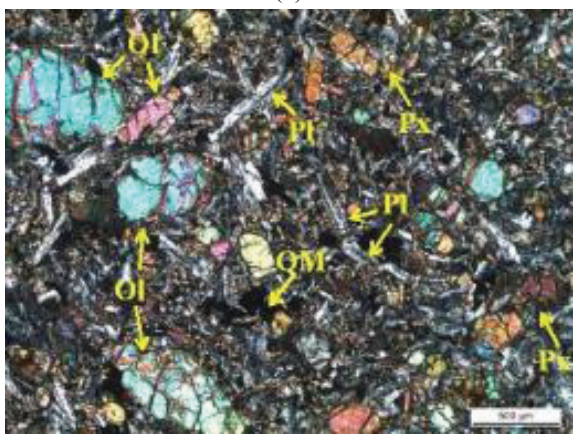

(c)

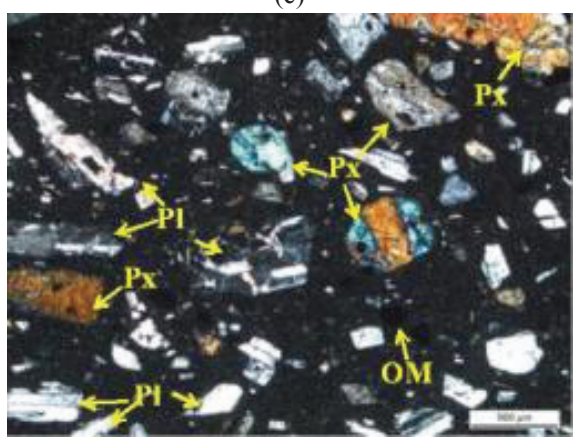

(e)

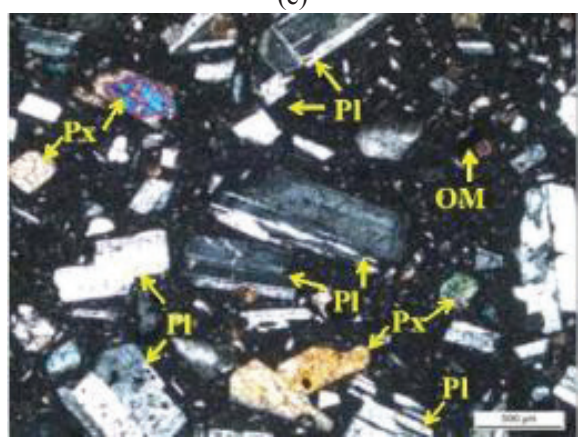

(g)

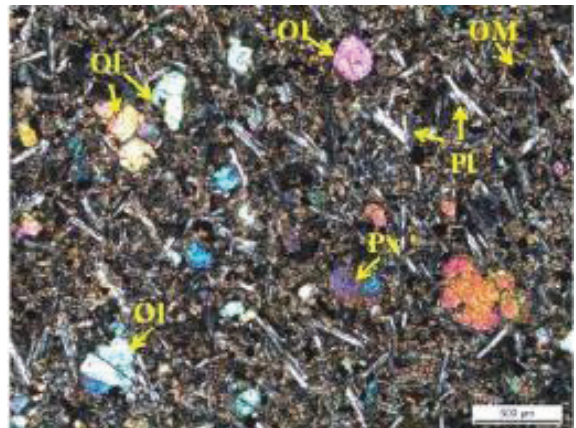

(b)

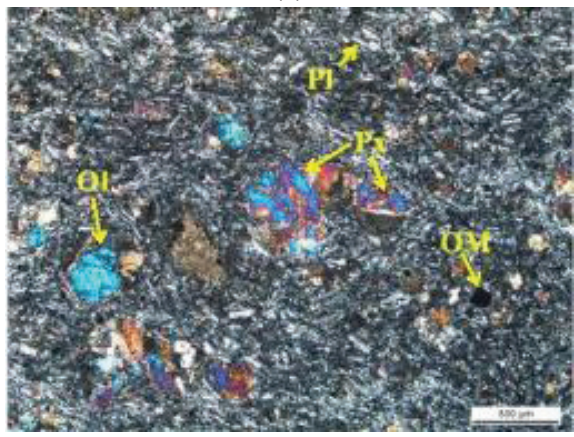

(d)

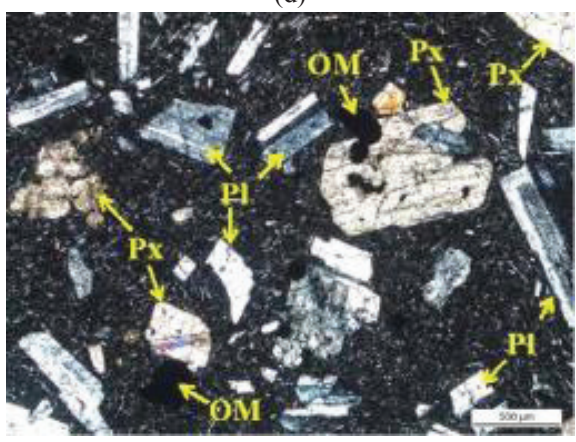

(f)

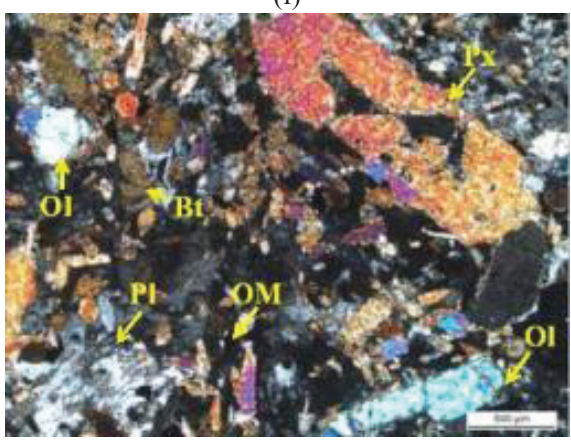

(h)

Şekil 4. Örneklerin polarizan mikroskobu altındaki görünümü.

Figure 4. View of samples under polarizing microscope.

a) BTH, b) BTM, c) BTO, d) BK, e) BD, f) BÇ g) BB, h) BE, (Px: Piroksen, Pl: Plajiyoklas, Ol: Olivin, OM:

Opak Mineral), (Çift Nikol. 4X). 


\section{Fiziksel ve Mekanik Özellikler}

\section{Yoğunluk}

Fiziksel özelliklerden biri olan yoğunluk deneyi ISRM (2007)' e uygun olarak yapılmış ve elde edilen ortalama sonuçlara göre en yüksek değerin $2.74 \mathrm{t} / \mathrm{m}^{3}$ ile BTH örneğine ve en düşük değerin $2.47 \mathrm{t} / \mathrm{m}^{3}$ ile BÇ örneklerine ait olduğu Çizelge 6' da görülmektedir.

Çizelge 6. Bazaltik kayaçların yoğunluk değerleri.

Table 6. Density values of the basaltic rocks.

\begin{tabular}{cccc}
\hline Ocak Kodu & \multicolumn{3}{c}{ Yoğunluk $\left(\mathrm{t} / \mathrm{m}^{3}\right)$} \\
& En Yüksek & En Düşük & Ortalama \\
\hline BTH & 2.74 & 2.74 & 2.74 \\
BTM & 2.74 & 2.73 & 2.74 \\
BTO & 2.66 & 2.64 & 2.65 \\
BK & 2.57 & 2.57 & 2.57 \\
BD & 2.49 & 2.48 & 2.49 \\
BÇ & 2.47 & 2.46 & 2.47 \\
BB & 2.50 & 2.48 & 2.49 \\
BE & 2.69 & 2.69 & 2.69 \\
\hline
\end{tabular}

\section{Birim Hacim Ağırlık}

Birim hacim ağırlık deneyi ISRM (2007)' e göre yapılmıştır. Çizelge 7' de verilen sonuçlara göre; en yüksek ortalama değer $28.69 \mathrm{kN} / \mathrm{m}^{3}$ ile BTH ve en düşük ortalama değer de $26.05 \mathrm{kN} / \mathrm{m}^{3}$ ile BB örneğidir.
Çizelge 7. Bazaltik kayaçların birim hacim ağırlık değerleri.

Table 7. Unit weight values of the basaltic rocks.

\begin{tabular}{cccc}
\hline \multirow{3}{*}{ Ocak Kodu } & \multicolumn{3}{c}{$\begin{array}{c}\gamma \\
\left(\mathrm{kN} / \mathrm{m}^{3}\right)\end{array}$} \\
\cline { 2 - 4 } & En Yüksek & En Düşük & Ortalama \\
\hline BTH & 28.78 & 28.60 & 28.69 \\
BTM & 28.54 & 28.48 & 28.51 \\
BTO & 28.08 & 28.06 & 28.07 \\
BK & 27.10 & 27.08 & 27.09 \\
BD & 26.35 & 26.19 & 26.27 \\
BÇ & 26.55 & 26.46 & 26.50 \\
BB & 26.06 & 26.04 & 26.05 \\
BE & 27.98 & 27.79 & 27.89 \\
\hline
\end{tabular}

\section{Efektif Gözeneklilik}

Farklı sektörlere hizmet edebilecek özelliklere sahip olan bazaltik kayaçların diğer tüm kayaçlarda olduğu gibi porozite değerinin bilinmesi önem arz etmektedir. Sekiz farklı bazaltik kayaç örneğinin de boşlukları birbirleri ile bağlantılı değildir. ISRM (2007) deney standardına göre yapılan deneylerden elde edilen efektif porozite sonuçları Çizelge 8 'de sunulmuştur. 
Erişiş, Tuğrul, Er, Yılmaz

Çizelge 8. Bazaltik kayaçların efektif porozite değerleri.

Table 8. Effective porosity values of the basaltic rocks.

\begin{tabular}{cccc}
\hline Ocak Kodu & \multicolumn{3}{c}{$\mathrm{n}_{\mathrm{e}}(\%)$} \\
\hline & En Yüksek & En Düşük & Ortalama \\
\hline BTH & 0.63 & 0.45 & 0.53 \\
BTM & 0.84 & 0.81 & 0.82 \\
BTO & 2.06 & 1.52 & 1.72 \\
BK & 1.20 & 1.10 & 1.14 \\
BD & 0.15 & 0.13 & 0.14 \\
BÇ & 0.36 & 0.32 & 0.33 \\
BB & 0.48 & 0.43 & 0.46 \\
BE & 2.25 & 1.94 & 2.05 \\
\hline
\end{tabular}

\section{Helyum Porozimetresi}

Helyum porozimetre deneyi efektif poroziteyi tespit edebilmek için uygulanan yöntemlerden biridir. Deney helyum gazının diğer gazlara göre daha küçük molekül yapısında olmasından ötürü kayacın çok daha küçük boşluklarına girebilme prensibine dayanmaktadır. Deney EPS Helium Gas Expansion Porosimeter HPG 100 (93115 A) model cihaz kullanılarak yapılmıştır. NQ çaplı karotlar cihaza uygun hale getirilerek çap1 $3.8 \mathrm{~cm}$, boyu ise $7.6 \mathrm{~cm}$ olacak şekilde yeniden hazırlanmış ve boyu kısa kalan numuneler için ise referans hacimler kullanılmıştır (Şekil 5).

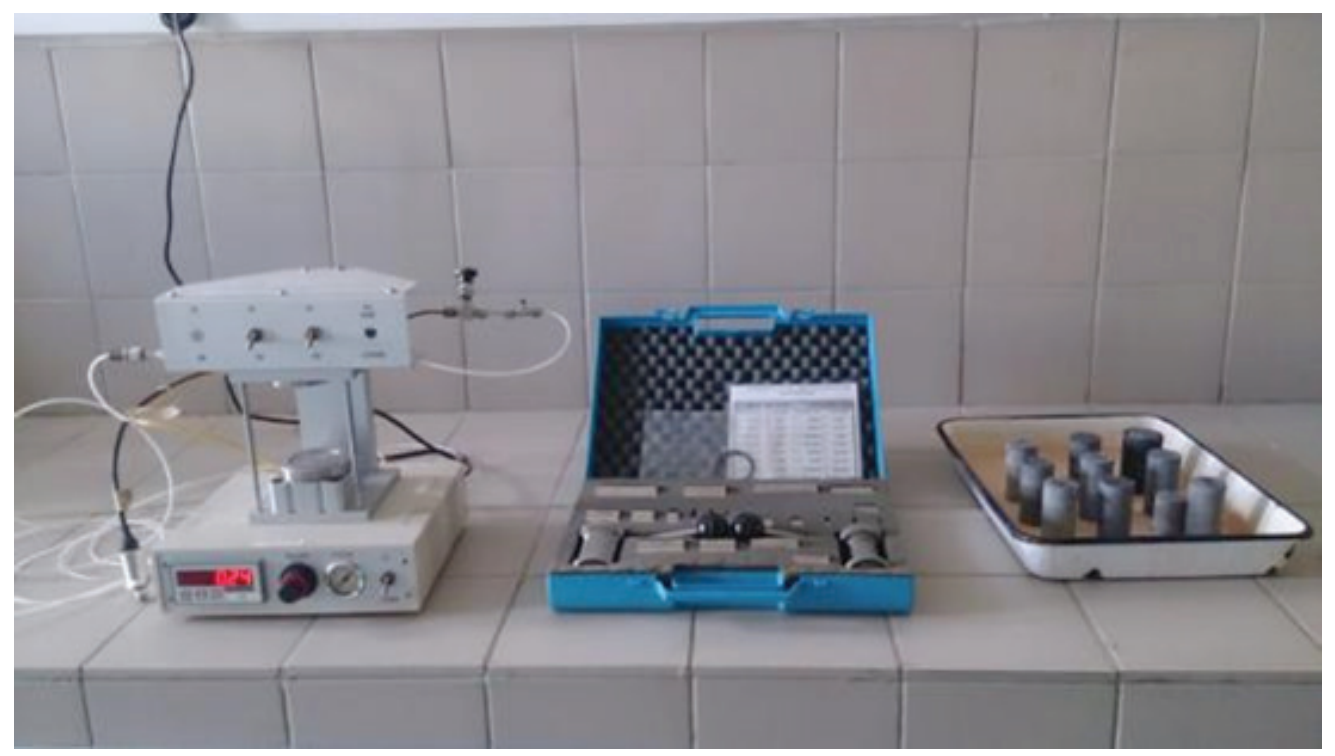

Şekil 5. Helyum porozimetresi cihazı ile referans ağırlıkları ve deneye uygun hale getirilmiş bazaltik kayaç örnekleri (soldan sağa doğru).

Figure 5. Reference weights and basaltic rock samples with the helium porosimetry device (from left to right). 
Anovitz ve Cole (2015)'e göre, helyum gazı diğer gazlara göre daha avantajlıdır çünkü;

(1) Küçük molekül yapısında olduğundan çok küçük gözeneklere nüfuz edebilir.

(2) $\mathrm{H}_{2} \mathrm{O}$ veya $\mathrm{CO}_{2}$ hava koşullarında kaya yüzeyine etkimeyebilir ve emilmeyebilir.

(3) Helyum, deneylerde kullanılan basınç ve sıcaklıklar için ideal gaz olarak kabul edilir.

(4) Helyum yüksek yayılma özelliğinde olduğundan düşük geçirgenliğe sahip kayaçların porozitelerini hesaplamak için doğru bir araçtır.

$\mathrm{Bu}$ nedenle helyum porozimetresi yöntemi ile elde edilmiş sonuçlar su kullanılarak elde edilen yönteme göre daha yüksek sonuçlar vermiştir. Deney sonuçlarına göre, en yüksek efektif porozite \% 14.8 ve boşluk hacmi $8.22 \mathrm{~mm}^{3}$ değerleri ile BE örneğine aittir. BE örneğinin diğerlerine göre daha yüksek değer vermesinin sebebi, ince kesitlerinde de dikkati çeken gaz boşlukları olduğu düşünülmektedir. En düşük efektif porozite \%1.5 ve boşluk hacmi $1.22 \mathrm{~mm}^{3}$ değerleri ile BD kodlu örneğe aittir. Çizelge 9'da helyum porozimetresi sonuçları verilmiştir. Helyum porozimetresinden elde edilen değerler ile ISRM önerilerine göre bulunmuş efektif porozite $\left(\mathrm{n}_{\mathrm{e}}\right)$ değerleri karşılaştırıldığında sonuçların uyumlu $(\mathrm{R}=0.81)$ olduğu görülmüştür (Şekil 6). Palchik ve Hatzor (2004), karbonatlı kayaçlar için bu uyumluluğu çok daha yüksek $\left(\mathrm{R}^{2}=0.99\right)$ olarak bulmuştur. Bazı sonuçların beklenilen dışında daha yüksek veya daha düşük çıkmasının nedeninin birbirleri ile bağlantılı olmayan gaz boşluklarından kaynaklandığı düşünülmektedir.
Çizelge 9. Bazaltik kayaçların helyum gazı yöntemi ile elde edilen efektif porozite ve boşluk hacmi değerleri.

Table 9. Effective porosity and void volume values obtained by helium gas method of the basaltic rocks.

\begin{tabular}{ccc}
\hline Örnek Kodu & Efektif Porozite & Boşluk Hacmi \\
\hline & $\Phi(\%)$ & $\left(\mathrm{mm}^{3}\right)$ \\
\hline BTH & 1.8 & 1.24 \\
BTM & 2.1 & 1.85 \\
BTO & 5.6 & 3.17 \\
BK & 2.2 & 1.84 \\
BD & 2.1 & 1.83 \\
BÇ & 1.5 & 1.22 \\
BB & 2.5 & 2.14 \\
BE & 14.8 & 8.22 \\
\hline
\end{tabular}

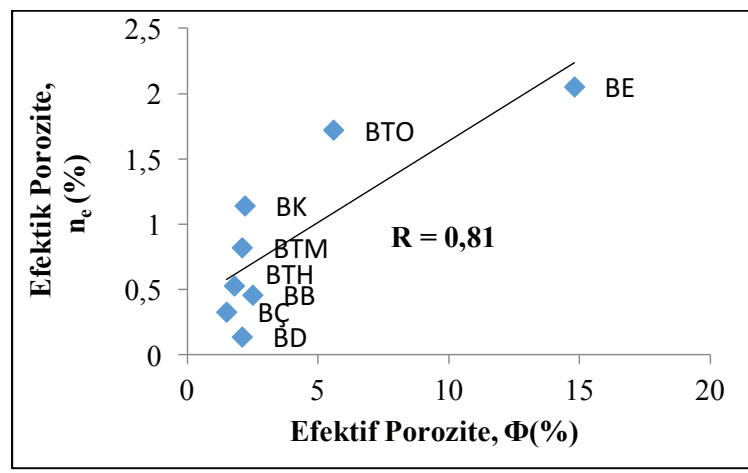

Şekil 6. İki farklı yöntem ile elde edilen efektif porozite değerleri arasındaki ilişki.

Figure 6. The relationship between the effective porosity values obtained by two different methods.

\section{Atmosfer Basınci Altında Su Emme}

Deney, ISRM (2007) önerisine göre gerçekleştirilmiştir. Çizelge 10'daki sonuçlara göre BE atmosfer basıncında \% 0.77 ile ağırlıça en yüksek su emmeye sahiptir. BD örneği içerisinde ayrışmış mineral bulunmadığ için, ortalama \% 0.06 su emme ile en düşük değeri sunmaktadir. 
Erişiş, Tuğrul, Er, Yılmaz

Çizelge 10. Atmosfer basıncı altında ağırlıç̧a su emme deney sonuçları.

Table 10. Water absorption test results under atmospheric pressure.

\begin{tabular}{cccc}
\hline Örnek & \multicolumn{3}{c}{$\mathrm{w}_{\mathrm{a}}(\%)$} \\
\cline { 2 - 4 } Kodu & En Yüksek & En Düşük & Ortalama \\
\hline BTH & 0.23 & 0.17 & 0.19 \\
BTM & 0.31 & 0.30 & 0.30 \\
BTO & 0.79 & 0.57 & 0.65 \\
BK & 0.47 & 0.43 & 0.45 \\
BD & 0.06 & 0.05 & 0.06 \\
BÇ & 0.14 & 0.13 & 0.14 \\
BB & 0.19 & 0.17 & 0.18 \\
BE & 0.84 & 0.73 & 0.77 \\
\hline
\end{tabular}

BE örneğinin efektif porozite değeri en fazla olduğundan, su emme değeri de en yüksektir. Aynı şekilde BD örneğinin efektif porozitesinin en düşük olmasına bağlı olarak su emmesi en düşük değere sahiptir.

\section{P Dalga Hızı}

Pdalgahızı deneyi ISRM(2007)'deönerildiği gibi en az beş karot örneği üzerinde Proceq marka ultrasonik ses geçirgenlik cihazı kullanılarak yapılmıştır (Şekil 7). Ultrasonik P dalga hızı, ölçümü yapılan numunenin yoğunluğuna, porozitesine ve dokusal özelliklerine bağlı olarak değişim göstermektedir. Çizelge 11'de gösterildiği üzere en yüksek ortalama değer $6.331 \mathrm{~km} / \mathrm{sn}$ ile THB örneğine, en düşük P dalga hızı değeri ise $5.458 \mathrm{~km} / \mathrm{sn}$ ile BB örneğine aittir.

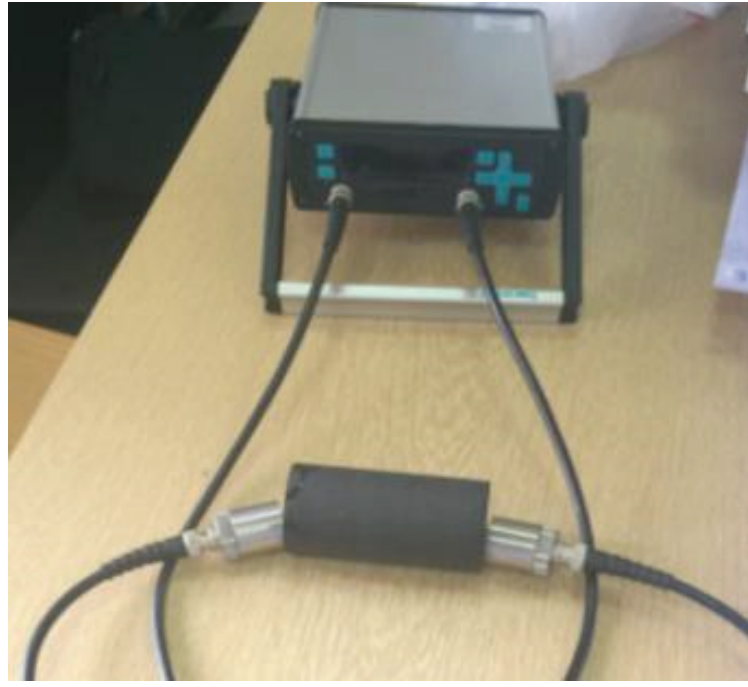

Şekil 7. Ultrasonik ses geçirgenlik cihazı ile P dalga hızı ölçümü.

Figure 7. P wave velocity measurement with ultrasonic sound transmittance device.

Çizelge 11. Bazaltik kayaçların P dalga hızı sonuçları. Table 11. Results of $P$ wave velocity of the basaltic rocks.

\begin{tabular}{cccc}
\hline Örnek & \multicolumn{3}{c}{ Vp $(\mathrm{km} / \mathrm{sn})$} \\
\cline { 2 - 4 } Kodu & En yüksek & En düşük & Ortalama \\
\hline BTH & 6.415 & 6.289 & 6.331 \\
BTM & 6.159 & 6.159 & 6.159 \\
BTO & 5.917 & 5.732 & 5.834 \\
BK & 5.632 & 5.632 & 5.632 \\
BD & 5.915 & 5.621 & 5.776 \\
BÇ & 5.805 & 5.587 & 5.674 \\
BB & 5.587 & 5.258 & 5.458 \\
BE & 5.920 & 5.531 & 5.732 \\
\hline
\end{tabular}

\section{Tek Eksenli Basınç Dayanımı}

Deney ISRM (2007)'de önerilen yönteme göre gerçekleştirilmiştir. Çizelge 12'de verilen sonuçlara göre hamur oranı en fazla olan BTH örneği ortalama $271 \mathrm{MPa}$ değeri ile en yüksek basınç dayanımına sahiptir. Mineral içeriği en 
fazla olup, aynı zamanda efektif porozite değeri de diğer bazaltlara nispeten çok daha yüksek olan BE örneği ise ortalama $145 \mathrm{MPa}$ değeri ile en düşük dayanımı vermektedir. BTH, BTM, BTO ve BK örnekleri sadece hamur oranları en fazla olan örnekler olmamakla birlikte aynı zamanda hamur bileşiminde bulunan piroksen ve plajiyoklasların, volkan camından çok daha fazla olduğu örnekler olarak diğer bazaltlara göre daha yüksek basınç dayanımlarına sahiptir.

BE örneğindeki gaz boşlukları, BK örneğinin hamurundaki akma dokusu, BTO örneğinin de psödomorf boşluklu yapısı, bu kayaçlarda fiziksel ve mekanik zayıflıklara neden olmaktadır. Buna bağlı olarak da basınç dayanımları beklenilenden daha düşük değerler vermektedir.

Çizelge 12. Bazaltik kayaçların tek eksenli basınç deneyi sonuçları.

Table 12. Uniaxial compressive strength test results of the basaltic rocks.

\begin{tabular}{lccc}
\hline \multirow{2}{*}{$\begin{array}{l}\text { Örnek } \\
\text { Kodu }\end{array}$} & \multicolumn{3}{c}{ Tek Eksenli Basınç Dayanımı, $\sigma_{\mathrm{c}}(\mathrm{MPa})$} \\
\cline { 2 - 4 } & En Düşük & En Yüksek & Ortalama \\
\hline BTH & 208 & 320 & 271 \\
BTM & 194 & 287 & 247 \\
BTO & 160 & 270 & 206 \\
BK & 197 & 253 & 216 \\
BD & 167 & 280 & 190 \\
BÇ & 134 & 267 & 188 \\
BB & 133 & 257 & 186 \\
BE & 102 & 218 & 145 \\
\hline
\end{tabular}

\section{Elastisite Modülü ve Poisson Oranı}

Elastisite modülü ve Poisson oranı ISRM (2007) önerileri dikkate alınarak yapılan tek eksenli basınç deneyi sırasında deformasyon ölçerler yardımıyla (Şekil 8) bulunmuştur. Çizelge 13'te görüldüğü üzere ortalama en yüksek Poisson oranı değeri 0.28 ve $117 \mathrm{GPa}$ elastisite modülü değeri ile BTH örneğine aittir. En düşük Poisson oranı değeri 0.14 ile BK örneği ve en düşük elastisite modülü ise $57 \mathrm{GPa}$ değeri ile BÇ örneğine aittir. Palchic (2013)'e göre; elastisite modülü, basınç dayanımı ve efektif porozite değerleri ile uyumluluk gösterse de Çizelge 13'te verilmiş olan değerlere göre bazaltik kayaçlarda elastisite modülü böyle anlamlı bir ilişki vermemiştir. Bunun durumun, kayacın bileşiminden bağımsız olarak var olan mikro çatlak sistemlerinin ve porozitelerinin erken yenilmelere sebebiyet vermesinden kaynaklanabileceği düşünülmektedir. İkinci neden ise, kayacın elastik davranışı ile kayacın dayanımı arasındaki ilişkiyi bozan örneklerden dolayı anlamlı bir regresyon analizi sonucu elde edilememiştir. Örneğin BK örneği yükssek dayanım gösterse bile, içerisinde bulunan ayrışmış mineraller ve mikro çatlaklarından dolay1 elastisite modülü düşük değer vermiştir.

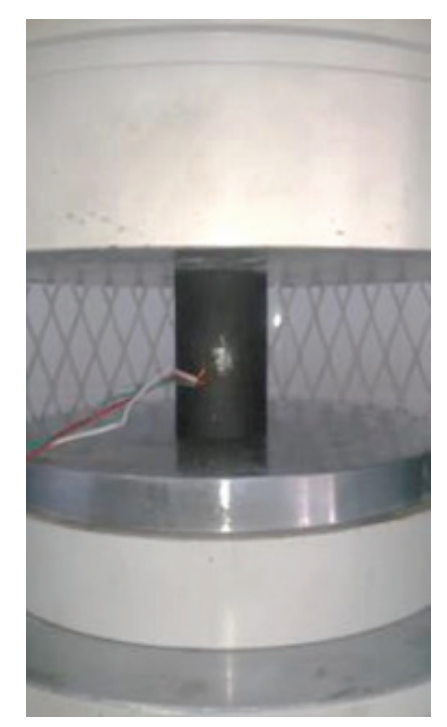

Şekil 8: Tek eksenli basınç deneyi sırasında bazalt örneği üzerine yapıştırılmış deformasyon ölçer.

Figure 8: Strain gauge on the basalt sample during the uniaxial compressive strength test. 
Erişiş, Tuğrul, Er, Yılmaz

Çizelge 13. Tek eksenli basınç dayanımı deneyi sırasında elde edilen Poisson oranı ve elastisite modülü değerleri.

Table 13. Poisson ratio and elasticity module values obtained during uniaxial compressive strength test.

\begin{tabular}{ccc}
\hline $\begin{array}{c}\text { Örnek } \\
\text { Kodu }\end{array}$ & $\begin{array}{c}\text { Poisson Oranı } \\
v\end{array}$ & $\begin{array}{c}\text { Elastisite Modülü } \\
\text { E(GPa) }\end{array}$ \\
\hline BTH & 0.28 & 117 \\
BTM & 0.24 & 65 \\
BTO & 0.18 & 90.5 \\
BK & 0.14 & 67 \\
BD & 0.20 & 101 \\
BÇ & 0.23 & 57 \\
BB & 0.18 & 76 \\
BE & 0.27 & 103 \\
\hline
\end{tabular}

\section{VERILERIN DEĞERLENDİRILMESİ VE TARTIŞMA}

Bazaltik kayaçların kimyasal, mineralojik ve petrografik özellikleri, fiziko-mekanik özellikleri ile karşılaştırılırken basit regresyon analizi yöntemi tercih edilmiştir. Bazaltik kayaçların kimyasal bileşiminde magnezyum, demir ve alüminyum elementlerini fazla bulunduran örneklerin yoğunluklarının ve birim hacim ağırlıklarının da yüksek olduğu belirlenmiştir. (Şekil 9). Ayrıca tek eksenli basınç dayanımı ile kıyaslandığında, korelasyon katsayısı $\mathrm{R}=0.78$ olan anlamlı bir ilişki elde edilmiştir. $\mathrm{Bu}$ hesaplamalarda BE kodlu bazalt, diğer örneklere göre yüksek efektif poroziteye sahip olması ve içeriğindeki minerallerde kısmen ayrışmış, öz kristal biçimlerini kaybetmiş olmasından ötürü karşılaştırmaya dahil edilmemiştir (Şekil 10).

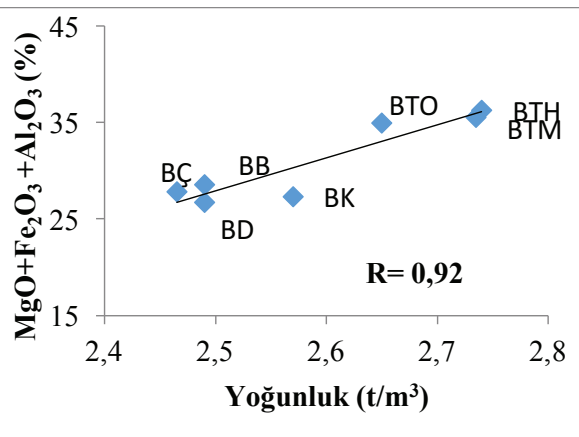

(a)

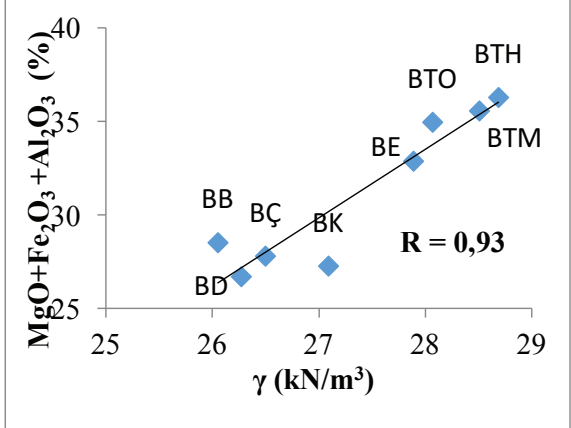

(b)

Şekil 9. Bazaltik kayaçların kimyasal bileşimleri ile a) yoğunluk ve b) birim hacim ağırlık değerlerinin karşılaştırılması.

Figure 9. Chemical composition of the basaltic rocks and a) density and b) unit weight values. 


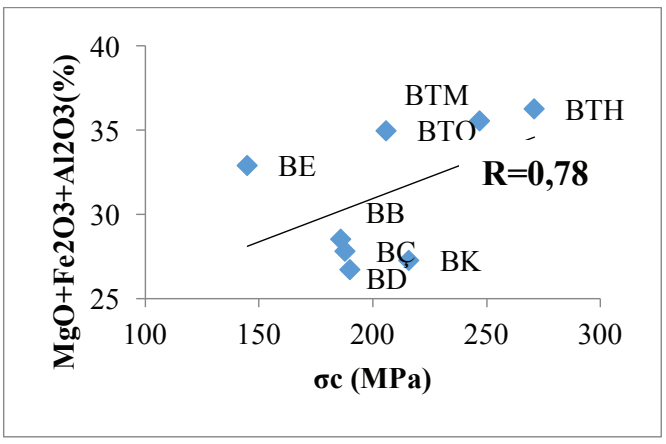

Şekil 10. Bazaltik kayaçların kimyasal bileşimi ve basınç dayanımı arasındaki ilişki.

Figure 10. The relationship between chemical composition and compressive strength of the basaltic rocks.
Eberhardt vd. (1999) ile Tuğrul ve Zarif (1999) granitik kayaçlar üzerinde yaptıkları çalışmalarda, kayacın mineralojik bileşimleri ile mekanik özelliklerini kıyasladıklarında tane boyu küçüldükçe dayanımın arttığını belirtmişlerdir. Ündül vd. (2015) andezitik kayaçlar üzerinde yaptıkları çalışmada; plajiyoklas ve amfibol toplamının, hamura olan oran1 (Plajiyoklas+Amfibol/Hamur) arttıkça dayanımlarının arttığını tespit etmişlerdir. Benzer bir çalışma bu araştırmada da yapılmıştır. Plajiyoklas, piroksen ve olivin fenokristal alanları toplanıp hamura oranlandığında, değer küçüldükçe, yani hamur oranı arttıkça tek eksenli basınç dayanımının arttığı belirlenmiştir (Şekil 11).

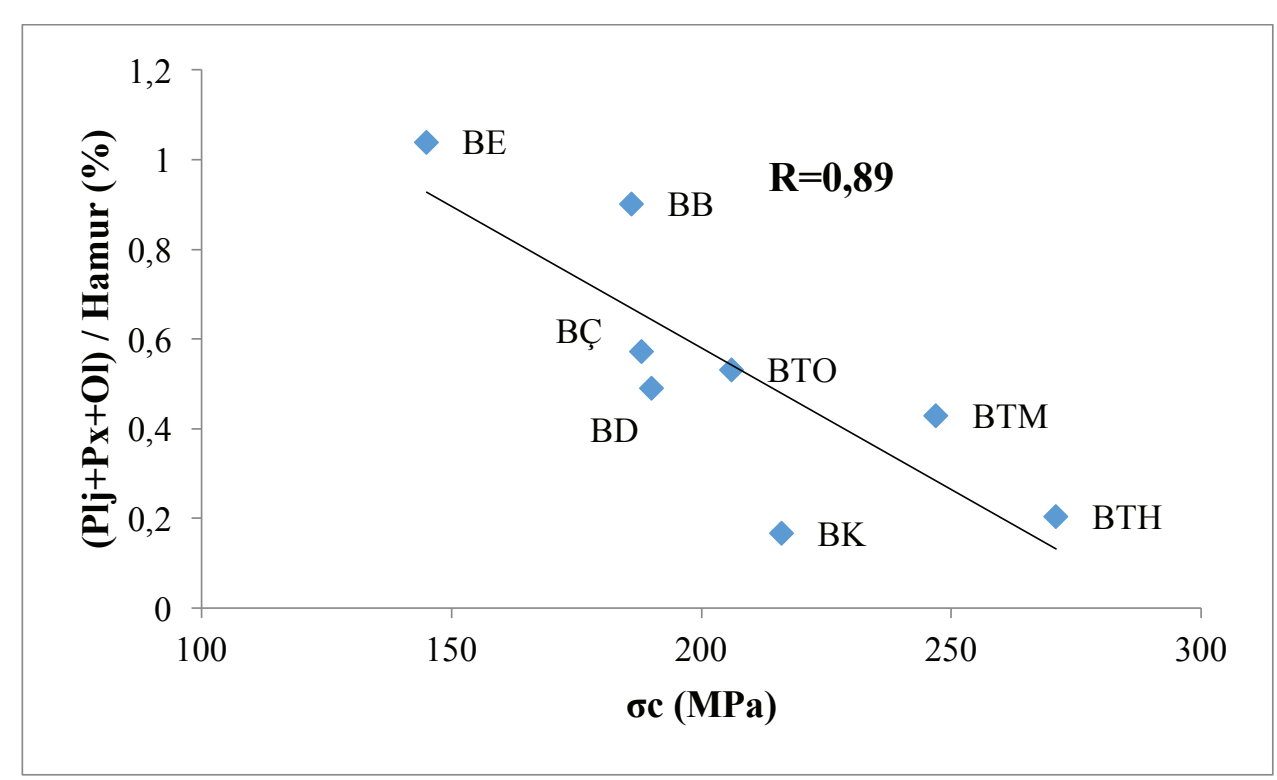

Şekil 11. Bazaltik kayaçların mineral alan yüzdelerinin hamur yüzdelerine oranının tek eksenli basınç dayanımı değerleri ile karşılaştırılması.

Figure 11. Comparison of the ratio between mineral area percentages and matrix percentage of the basaltic rocks with uniaxial compressive strength values. 
Erişiş, Tuğrul, Er, Yılmaz

Dayanımı etkileyen en önemli unsurlardan biri hamurun bileşimi ve özelliğidir. 8 farkl1 bazaltik kayaç içerisinde, piroksen, plajiyoklas ve olivin minerallerinin hamurun neredeyse tamamına hakim olduğu örnekler (BTH, BTM, BTO, BK) yüksek dayanım gösterirken, volkan camı ve plajiyoklas ağırlıklı olanlar (BD, BÇ, BB) daha düşük basınçlarda yenilmektedir. Bunun yanı sıra, hamur içerisinde fenokristal boyutlarda bulunan piroksen minerali boyutu arttıkça kayaçların dayanımı da düşmektedir. Benzer ilişki plajioklas fenokristal boyutu ile kayaçların dayanım arasında da bulunmasına rağmen piroksen ve kayaç dayanımı arasındaki ilişki kadar kuvvetli değildir. (Şekil 12). örneğinin dayanımlı hamur dokusuna rağmen, efektif porozite değerinin yüksek olmasıdır. BK örneğinde de hamurda var olan çatlak sistemleri, akma dokusu ve minerallerindeki ayrışmadan dolayı gözlenen killeşmeler nedeniyle dayanımı beklenilen değerden daha düşüktür. Bunların dışında hamuru volkan camı ağırlıklı olan BD örneği ise ayrışmış mineral içermediğinden yüksek dayanımlıdır. $\mathrm{Bu}$ şekilde kırılgan davranmasının nedeni, hamurunun ağırlıklı olarak volkan camından meydana gelmiş olması ve hamurdaki çatlaklardır.

Mineralojik ve petrografik özelikleri dikkate alındığında hamur - mineral oranlarına göre bazaltik kayaçlar kendi içlerinde uyumlu olarak

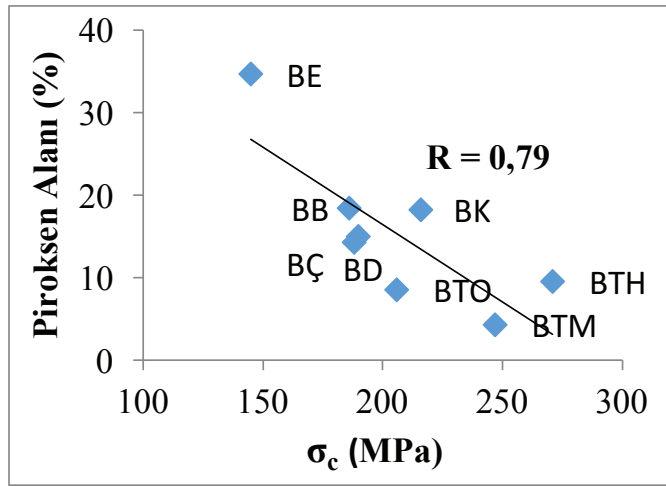

(a)

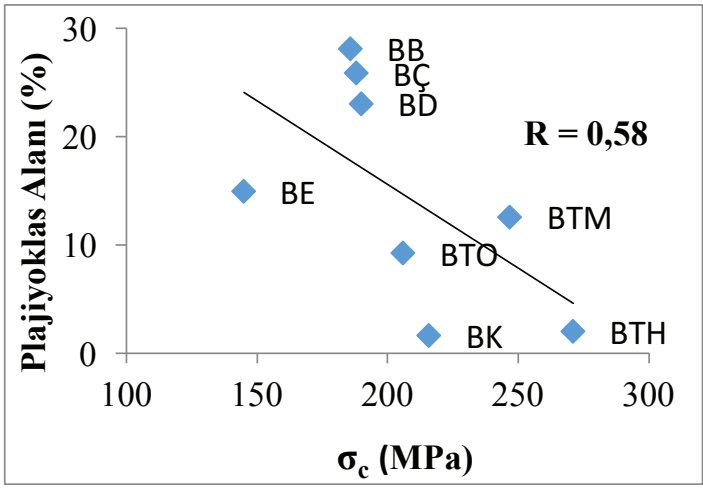

(b)

Şekil 12. Piroksen ve plajiyoklas fenokristal yüzdelerinin dayanım değerleri ile karşılaştırılması.

Figure 12. Comparison of pyroxene and plagioclase phenocrystalline percentages with strength values.

Çatlak ve ayrışmış mineral içermeyen kayaçlar, bunları içeren kayaçlara göre, yük altında daha uzun bir süre yenilmeden kalabilmektedir. Genel olarak dayanımı yüksek olan BTH ve BTM örneklerinde, yenilmenin meydana geldiği yük değerleri de yüksektir. Fakat benzer petrografik özellikler gösteren BTO ve BK örneklerinin dayanımları beklenilenden nispeten daha düşüktür. Bunun nedeni BTO belli fiziksel ve mekanik değerler vermektedir. $\mathrm{Bu}$ değerler bazaltik kayaçların bileşim ve dokusal özelliklerine göre gruplandırılabileceğini göstermektedir. Şekil 13'te görüldüğü gibi üst sırada yer alan bazaltların mineral tane boyları ve alanları küçük olup, bileşimlerinde bulunan olivin, piroksen, plajiyoklas ve opak mineral fenokristal toplamları \%18 - 36 arasinda değişmektedir. Ayrıca hamurları piroksen, 
plajiyoklas ve daha az olivin bileşimli olarak görülmektedir. $\mathrm{Bu}$ grupta yer alan bazaltlar diğerlerine göre daha dayanımlı ve fiziksel özellikleri (yoğunluk ve birim hacim ağırlıkları yüksek) benzerdir. 2. grubu oluşturan ve şeklin alt sirasında bulunan bazaltların mineral boyutları ve alanları daha büyük olup, bileşimlerinde yer alan plajiyoklas, piroksen ve opak mineral (BE örneğinde istisnai olarak \%1.59 oranında olivin de vardır) fenokristal toplamları \% 40-55 arasinda değişmektedir. Hamurlarının bileşimi ağırlıklı olarak volkan camı ve plajiyoklas mikrolitinden meydana gelmektedir. Bu grupta yer alan bazaltlar, diğer gruptakilere göre ortalama \% 25 daha düşük dayanımlı olup, yoğunlukları ve birim hacim ağırlıkları da daha düşüktür.

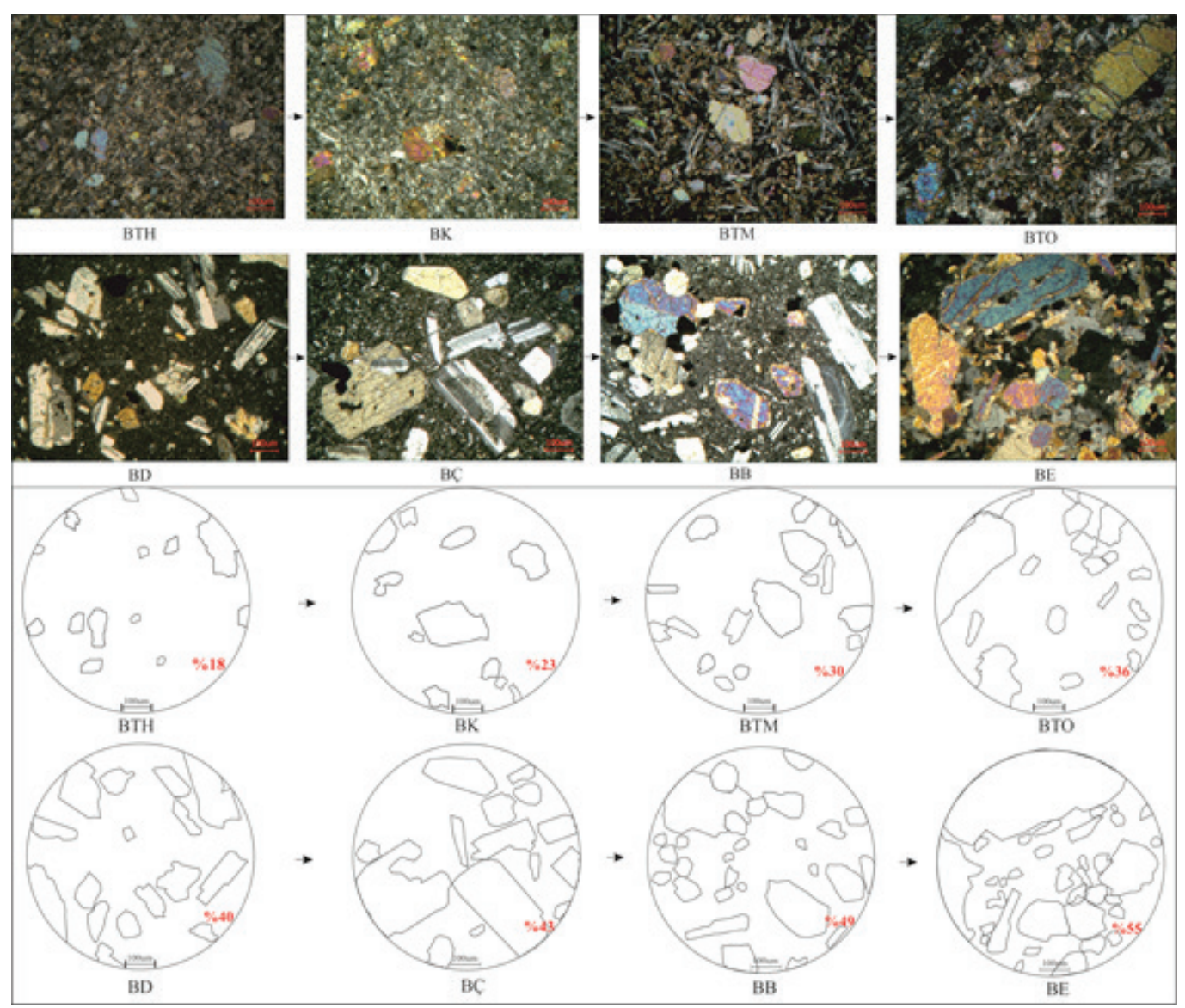

Şekil 13. Bazaltik kayaçların bileşim ve dokusal özelliklerine göre sınıflandırılması.

Figure 13. Classification of the basaltic rocks according to composition and textural characteristics. 
Erişiş, Tuğrul, Er, Yılmaz

Bazaltların hamur bileşimleri, mineral içerikleri, fiziksel ve mekanik özellikleri dikkate Şekil 14'te ve bu grupların ortalama fiziksel ve alınarak öngörülmüş olan gruplandırması mekanik değerleri Șekil 15 'te sunulmuștur.
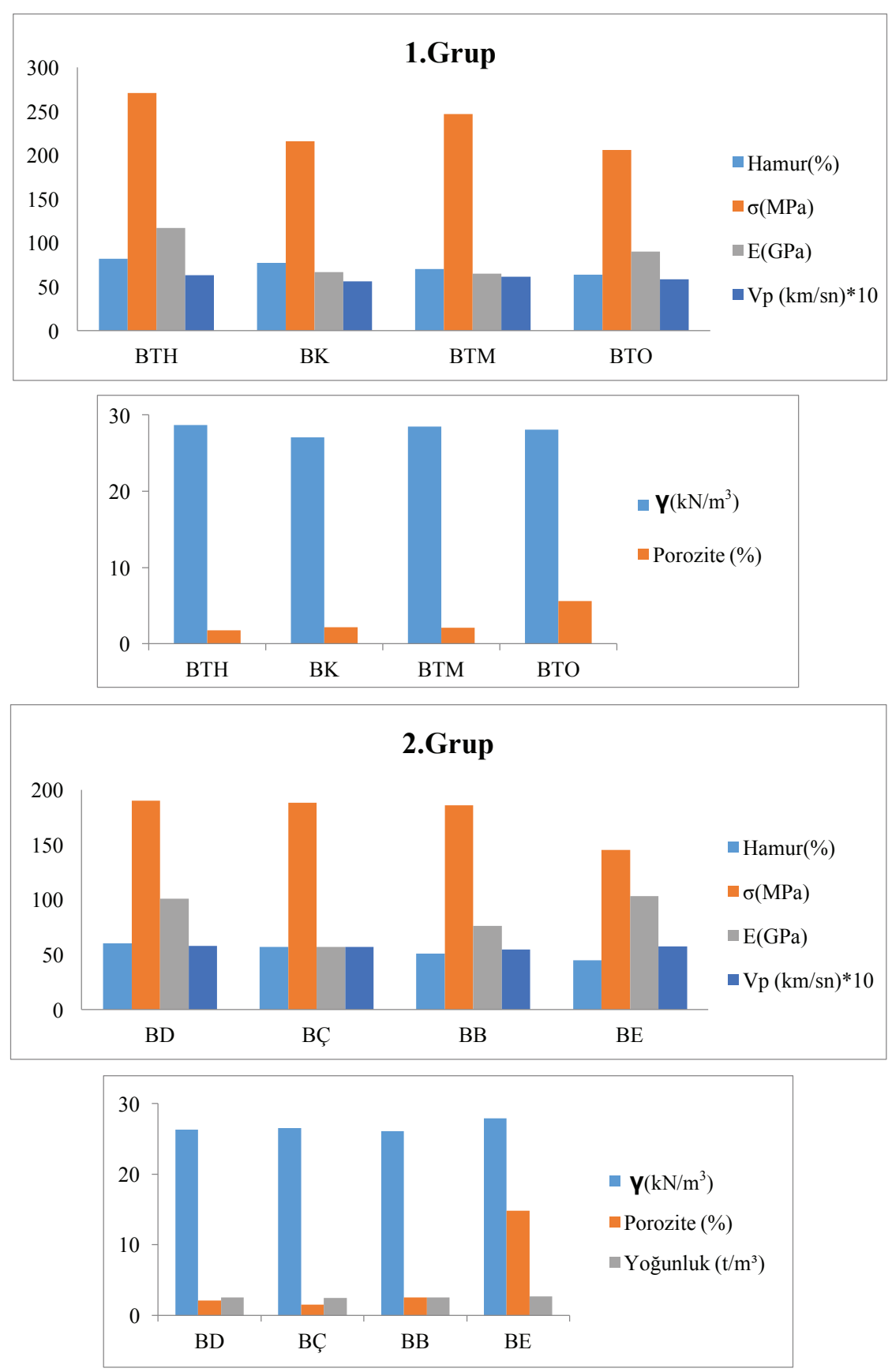

Şekil 14. Bazaltik kayaçların petrografik, mekanik ve fiziksel özelliklerine göre gruplandırılması.

Figure 14. Grouping of the basaltic rocks by petrographic, mechanical and physical properties. 

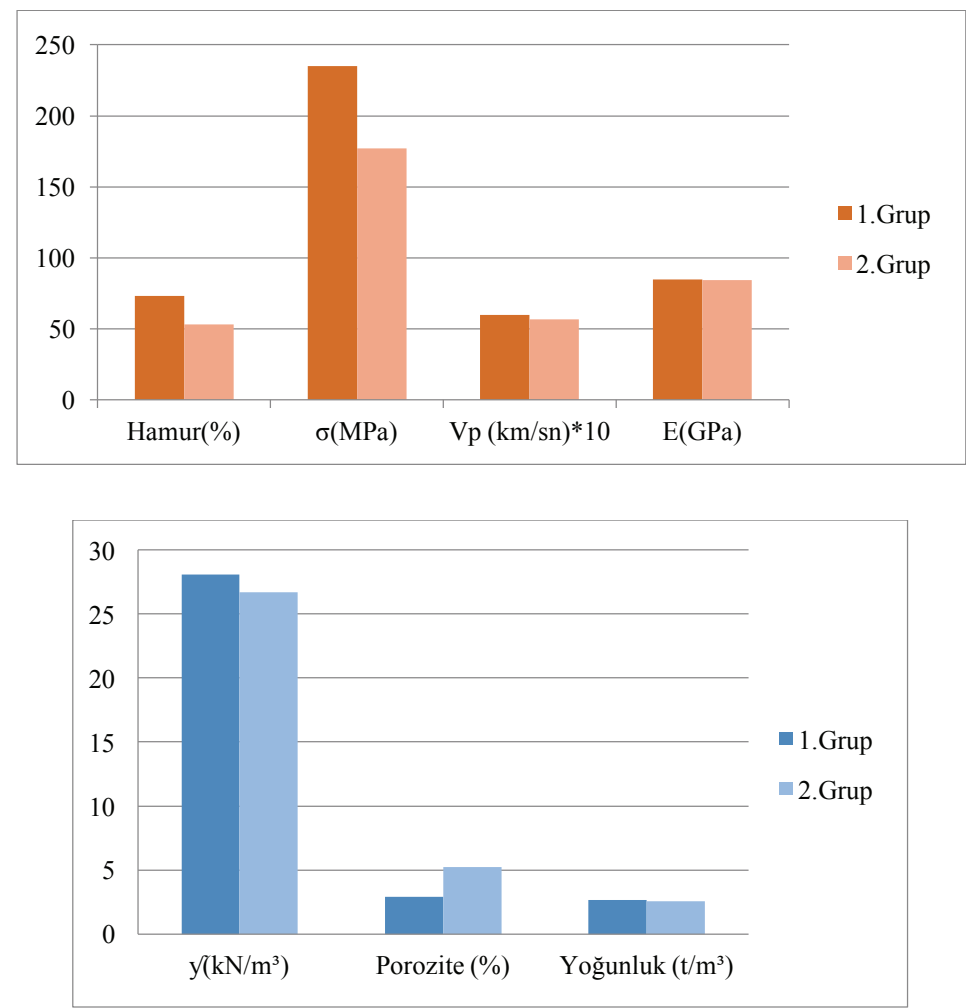

Şekil 15. Dokusal özelliklerine göre gruplandırılmış bazaltik kayaç örneklerinin ortalama mekanik ve fiziksel değerleri.

Figure 15. Average mechanical and physical values of the basaltic rock samples grouped according to their textural properties.

\section{SONUÇLAR}

Bazaltların; hamur bileşimi, mineral içeriği, dokusu, fenokristal boyutları ve bunların kayaç içerisindeki yüzdeleri, bu kayaçların fiziksel ve mekanik özelliklerini etkilemektedir. Bazalt örneklerinin mineralojik ve petrografik niteliklerinin, fiziksel özellikleri ve mekanik davranışları üzerine olan etkisi göz önüne alınarak; incelenen örnekler dahilinde bazaltların hamur ve mineral bileşimlerine göre iki gruba ayrılması uygun görülmüştür. $\mathrm{Bu}$ gruplandırma doğrultusunda;

1. grupta yer alan bazaltlar;

-Genel olarak olivinli bazaltlardır,
-Hamur ağırlıklı olarak; olivin, piroksen, plajiyoklas minerallerinden oluşmaktadır,

-Fenokristal boyuttaki minerallerin alanları $\% 18$ ile \%36 arasında olup; bu özelliklerinden dolayı;

$>$ Yoğunluk ve birim ağırlık değerleri yüksektir,

$>$ Basınç dayanımları 2. gruba göre daha yüksek ve ortalama $206 \mathrm{MPa}$ ile $271 \mathrm{MPa}$ arasında değişmektedir.

2. grupta yer alan bazaltlar;

-Genel olarak olivinsiz bazaltlardır, 
-Hamur ağırlıklı olarak; plajiyoklas mikroliti ve volkan camından oluşmaktadır,

-Fenokristal boyuttaki minerallerin alanları $\% 40$ ile $\% 55$ arasındadır ve tüm bu özellikleri nedeniyle;

$>$ Yoğunluk ve birim ağrılık değerleri 1. gruba göre daha düşüktür,

> Basınç dayanımları daha düşük ve ortalama $145 \mathrm{MPa}$ ile $190 \mathrm{MPa}$ arasinda değişmektedir.

$\mathrm{Bu}$ çalışma kapsamında öngörülmüş olan gruplandirma, bazalt örneklerinin çeşitliliği (mineralojik, petrografik, fiziksel ve mekanik özellikleri doğrultusunda) arttırılarak geliştirilebilir.

\section{KATKI BELIRTME}

$\mathrm{Bu}$ çalışma İstanbul Üniversitesi Bilimsel Araştırma Projeleri Yürütücü Sekreterliği’nin 51152 numaralı projesi ile desteklenmiştir.

\section{KAYNAKLAR}

Adelinet, M., Fortin, J., Schubnel, A., Guéguen, Y., 2013. Deformation modes in an Icelandic basalt: From brittle failure to localized deformation bands. Journal of Volcanology and Geothermal Research, 255, 15-25.

Anovitz, L.M., Cole, D.R., 2015. Characterization and analysis of porosity and pore structures. Rev Mineral Geochemistry, 80, 61-164.

Eberhardt, E., Stimpson, B., Stead, D., 1999. Effects of grain size on the initiation and propagation thresholds of gerilims-induced brittle fractures. Rock Mechanics Rock Engineering, 32(2), 8199.
Heap, M.J., 2009. The evolution of elastic moduli with increasing crack damage during cyclic gerilimsing of a basalt from Mt. Etna volcano. Tectonophysics, 471 (1-2), 153-160.

ISRM, 2007. The ISRM Suggested Methods for Rock Characterization, Testing and Monitoring, Springer, 628p.

Korkanç, M., Solak, B., 2016. Estimation of engineering properties of selected tuffs by using grain/matrix ratio. Journal of African Earth Sciences, Volume 120, August 2016, pages 160172.

Le Bas, M.J., Le Maitre, R.W., Streckeisen, A., Zanettin, B., 1986. A chemical classification of volcanic rocks based on total alkali-silica diagram. Journal of Petrology, 27, 745-750.

Palchik, V., Hatzor, Y. H., 2004. The influence of porosity on tensile and compressive strength of chalks, Rock Mechanics and Rock Engineering, 37(4), 331-341.

Palchik, V., 2013. Is there link between the type of the volumetric strain curve and elastic constants, porosity, stress and strain characteristics. Rock Mechanics and Rock Engineering, 46(2), 315326.

Tuğrul A., Gürpınar, O., 1997. Proposed Weathering Classification for Basalts and Their Engineering Properties. Bulletin of the International Association of Engineering Geology, 55, 61-71.

Tuğrul, A., Zarif, I. H., 1999. Correlation of Mineralogical and Textural Characteristics with Engineering Properties of Selected Granitic Rock from Turkey. Engineering Geology, 51, pp. 303- 317.

Ündül, Ö., Amann, F., Aysal, N., Plötze, M., 2015. Micro - textural effects on crack initiation and crack propagation of andesitic rocks. Engineering Geology, 1-9. 